\title{
Cholesterol embolization syndrome and intra-abdominal bleeding immediately after initiation of hemodialysis: a case report with literature review
}

\author{
Kota Kakeshita, Tsutomu Koike, Teruhiko Imamura* ${ }^{*}$, Yu Arisawa, Sayaka Murai, Ayako Shimizu, Taigo Kiyosawa, \\ Hidenori Yamazaki and Koichiro Kinugawa
}

\begin{abstract}
Background: Cholesterol embolization syndrome (CES) is a disease associating with the systemic cholesterol crystal embolism and end-organ dysfunction due to the atherosclerotic plaque rupture, which is dominantly triggered by the intravascular intervention. There is no consensus for which types of anticoagulants we should use during the hemodialysis in patients with CES and end-stage renal disease.

Case presentation: We had a 68-year-old man with CES due to intravascular intervention, who suffered the omental bleeding, instead of the embolism, immediately after the initiation of hemodialysis with heparinization. An emergent laparotomy found active bleeding from the omentum, which was surgically repaired. The histopathological analysis showed the embolization of cholesterol crystal clefts in the omentum artery and the injury of arterial wall structure accompanied by the infiltration of inflammatory cells. We preferred nafamostat mesylate during hemodialysis and he had no adverse events following the surgery.

Conclusions: It should be noticed that, in addition to the embolic events, bleeding events can develop in patients with CES, particularly following the initiation of hemodialysis with anticoagulation therapy.
\end{abstract}

Keywords: Cholesterol crystal embolization, Blue toe, Corticosteroid, Heparin

\section{Background}

Cholesterol embolization syndrome (CES) is a disease associating with the systemic cholesterol crystal embolism due to the atherosclerotic plaque rupture, which is dominantly triggered by the intravascular intervention. The disease has poor clinical outcomes including severe dermopathy and end-organ dysfunction [1].

We experienced a patient with CES triggered by the intravascular interventions who suffered the omental bleeding, instead of the embolism, immediately after the

\footnotetext{
* Correspondence: teimamu@med.u-toyama.ac.jp

The Second Department of Internal Medicine, University of Toyama, 2630 Sugitani, Toyama, Toyama 930-0194, Japan
}

introduction of hemodialysis. We might have to be careful of the bleeding comorbidities instead of embolism particularly while initiating hemodialysis in patients with CES.

\section{Case presentation On admission}

A 68-year-old man with a history of hypertension and diabetes mellitus as well as cigarette smoking received coronary angiography for the surveillance before the intervention to the abdominal aortic aneurysm (Fig. 1a), which showed multiple advanced stenosis in the coronary arteries. Serum creatinine on admission was $2.0 \mathrm{mg} /$

C C The Author(s). 2020 Open Access This article is licensed under a Creative Commons Attribution 4.0 International License, which permits use, sharing, adaptation, distribution and reproduction in any medium or format, as long as you give appropriate credit to the original author(s) and the source, provide a link to the Creative Commons licence, and indicate if changes were made. The images or other third party material in this article are included in the article's Creative Commons licence, unless indicated otherwise in a credit line to the material. If material is not included in the article's Creative Commons licence and your intended use is not permitted by statutory regulation or exceeds the permitted use, you will need to obtain permission directly from the copyright holder. To view a copy of this licence, visit http://creativecommons.org/licenses/by/4.0/. The Creative Commons Public Domain Dedication waiver (http://creativecommons.org/publicdomain/zero/1.0/) applies to the data made available in this article, unless otherwise stated in a credit line to the data. 

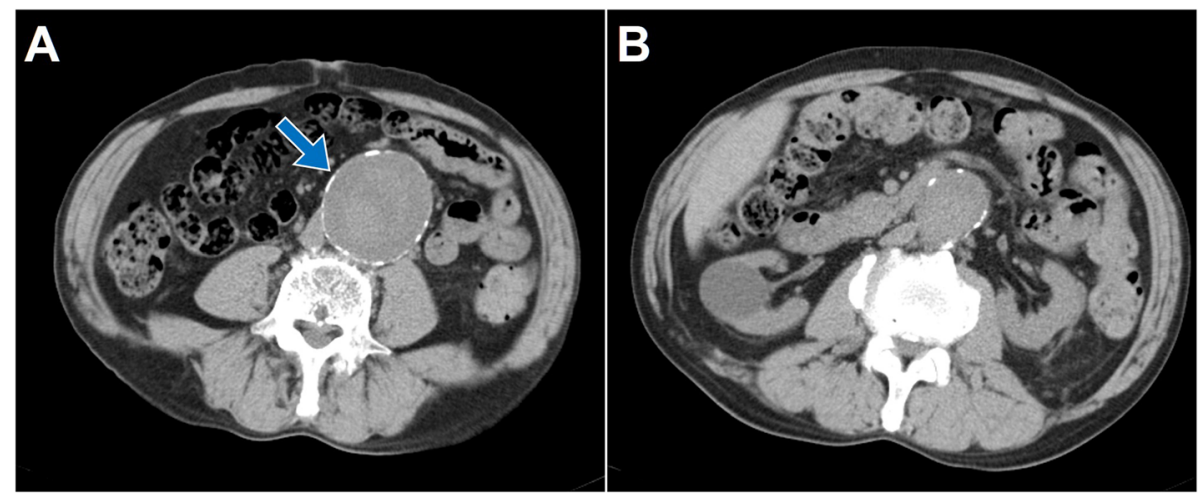

Fig. 1 Computed tomography findings on admission. a The blue arrow indicates abdominal aortic aneurysm. The maximum diameter was 60 $\mathrm{mm}$. b Bilateral renal atrophy. Renal cyst in the right kidney

$\mathrm{dL}$ and computed tomography showed bilateral renal atrophy (Fig. 1b). Following the initiation of low-dose aspirin, he underwent coronary artery bypass grafting 2 weeks later and endovascular aneurysm repair 4 weeks later.

Following these intravascular interventions, livedo reticularis and blue toe at bilateral foot developed (Fig. 2), accompanied by the increase in serum creatinine level (from 2.0 to $3.0 \mathrm{mg} / \mathrm{dL}$ ) and eosinophilia $(1300 / \mu \mathrm{L}$ ). The skin biopsy obtained from his right toe did not show any findings of CES. Renal function further deteriorated (serum creatinine increased up to $8.2 \mathrm{mg} / \mathrm{dL}$ ) as well as worsening of the above symptoms.

His body height was $168 \mathrm{~cm}$ and his body weight was $51.2 \mathrm{~kg}$. White blood cell count was $8170 / \mu \mathrm{L}$, eosinophil count was $610 / \mu \mathrm{L}$, hemoglobin was $8.7 \mathrm{~g} / \mathrm{dL}$, platelet count was $14.6 \times 10^{4} / \mu \mathrm{L}$, and low-density lipoprotein cholesterol was $133 \mathrm{mg} / \mathrm{dL}$ (Table 1).

\section{Initiation of hemodialysis}

Given the clinical presentation, we diagnosed him as CES and initiated the steroid therapy with oral prednisolone $0.5 \mathrm{mg} / \mathrm{kg} /$ day and the intermittent hemodialysis
(3 $\mathrm{h}$ per session and three times per week) with heparinization. We used unfractionated heparin at a standard procedure (1000 units bolus shot and 750 units/h continuous infusion). We did not monitor activated clotting time and activated partial thromboplastin time, but he experienced no device thrombosis and difficulty in hemostasis.

\section{After initiation of hemodialysis}

Five days following the initiation of hemodialysis, he presented acute abdominal pain and hemodynamic deterioration. Enhanced computed tomography showed active bleeding from the right gastroepiploic artery (Fig. 3). An emergent laparotomy found pulsatile active bleeding from the omentum with $3500 \mathrm{~mL}$ of hemoperitoneum, which was surgically repaired with an optimal result (Fig. 4a).

The histopathological analysis showed the embolization of cholesterol crystal clefts in the cavity of the omentum artery (Fig. 4b) and the injury of arterial wall structure accompanied by the infiltration of inflammatory cells (Fig. 4c), which would be the cause of hemoperitoneum.

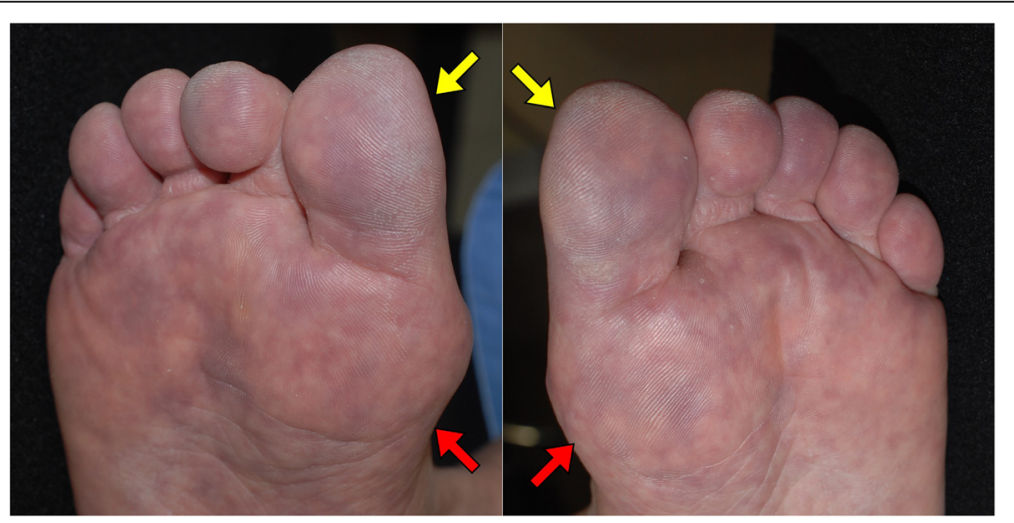

Fig. 2 Skin lesions in his bilateral lower limb. The yellow arrows indicate blue toe and the red arrows indicate livedo reticularis 
Table 1 Laboratory data at the time of CES diagnosis

\begin{tabular}{|c|c|}
\hline Laboratory test & Value \\
\hline \multicolumn{2}{|l|}{ Urinalysis } \\
\hline Urine specific gravity & 1.010 \\
\hline Urine protein & $(1+)$ \\
\hline Urine occult blood & $(-)$ \\
\hline Urine sugar & $(1+)$ \\
\hline \multicolumn{2}{|l|}{ Urine chemistry } \\
\hline Urine protein, $\mathrm{g} / \mathrm{g}$ of creatinine & 0.34 \\
\hline \multicolumn{2}{|l|}{ Urine sedimentation } \\
\hline Red blood cells, /high power field & $<1$ \\
\hline White blood cells, /high power field & $<1$ \\
\hline \multicolumn{2}{|l|}{ Complete blood cell counts } \\
\hline White blood cells, $/ \mu \mathrm{L}$ & 8170 \\
\hline Eosinophils, / $\mu \mathrm{L}$ & 610 \\
\hline Red blood cells, / $\mu \mathrm{L}$ & $275 \times 10^{4}$ \\
\hline Hemoglobin, g/dL & 8.7 \\
\hline Platelets, $/ \mu \mathrm{L}$ & $14.6 \times 10^{4}$ \\
\hline \multicolumn{2}{|l|}{ Serum chemistry } \\
\hline Total protein, g/dL & 6.8 \\
\hline Albumin, $\mathrm{g} / \mathrm{dL}$ & 3.6 \\
\hline Aspartate aminotransferase, IU/L & 19 \\
\hline Alanine aminotransferase, IU/L & 35 \\
\hline Lactate dehydrogenase, IU/L & 227 \\
\hline Blood urea nitrogen, mg/dL & 89 \\
\hline Creatinine, mg/dL & 8.2 \\
\hline Total cholesterol, mg/dL & 198 \\
\hline Low-density lipoprotein cholesterol, mg/dL & 133 \\
\hline High-density lipoprotein cholesterol, mg/dL & 16 \\
\hline Triglyceride, mg/dL & 162 \\
\hline Sodium, mEq/L & 134 \\
\hline Potassium, mEq/L & 4.5 \\
\hline Chloride, mEq/L & 103 \\
\hline Calcium, mg/dL & 8.6 \\
\hline \multicolumn{2}{|l|}{ Serum immunological test } \\
\hline Hemoglobin A1c, \% & 6.7 \\
\hline C-reactive protein, $\mathrm{mg} / \mathrm{dL}$ & 0.49 \\
\hline Antinuclear antibody & Negative \\
\hline Myeloperoxidase anti-neutrophil cytoplasmatic antibody & Negative \\
\hline Anti-glomerular basement membrane antibody & Negative \\
\hline
\end{tabular}

We preferred nafamostat mesylate during hemodialysis and he had no adverse events including bleeding following the surgery. Following the steroid therapy, eosinophilia improved immediately, and toe condition did not worsen. He remained dependent on the hemodialysis.
He was expired 6 months later due to sepsis, which was considered no association with CES.

\section{Discussion and conclusions CES in this case}

CES is a systemic disease of embolization of cholesterol crystal disseminated from the atherosclerotic plaque in the major artery [1]. The embolization causes both ischemia and inflammation including eosinophilia triggered by interleukin-5 secretion and multiple end-organ dysfunctions [2, 3].

The risk factors of CES are similar to those of conventional atherosclerosis, including hypertension, diabetes mellitus, dyslipidemia, smoking history, and male sex, most of which our patient accompanied [4]. The existence of abdominal aneurysm and intravascular interventions would have triggered the development of CES in our patient $[5,6]$.

\section{CES and end-stage renal failure}

CES has a considerable negative impact on kidney function, which is called athero-embolic renal disease $[7,8]$. Most of them develop within weeks following the intraarterial intervention. There are various reports associating with the prognosis of renal function following CES: $28-61 \%$ of cases required hemodialysis and partial improvement in renal function were observed in $21-39 \%$ of cases [1, 9-12]. Baseline higher serum creatinine level is a risk factor of hemodialysis following CES. Of note, multiple renal insults are associated with refractoriness to the recovery of renal function [10]. The patient also had renal sclerosis before the development of CES.

\section{Anticoagulation as a risk factor of CES}

Traditionally, anticoagulation therapy has been considered a trigger of CES given that anticoagulation might destabilize the plaque [13]. However, recent studies demonstrated that anticoagulation therapy during catheter intervention or coronary artery grafting did not have any impacts in the development of CES [6, 14]. Given these evidences, the current consensus states that there is no definite association between anticoagulation therapy and CES [4]. Nevertheless, another recent study showed that the secession of anticoagulation improved CES [11]. And anticoagulation therapy is by convention not recommended for the patients with CES in the daily clinical practice thus far [4].

Anticoagulation therapy is essential for the successful hemodialysis. We summarize the possible anticoagulants that might be applicable in patients with CES in Table 2. As shown, there is no consensus for which types of anticoagulants we should use for the hemodialysis in patients with CES and renal failure thus far. In general hemodialysis, we use heparin for the anticoagulation 


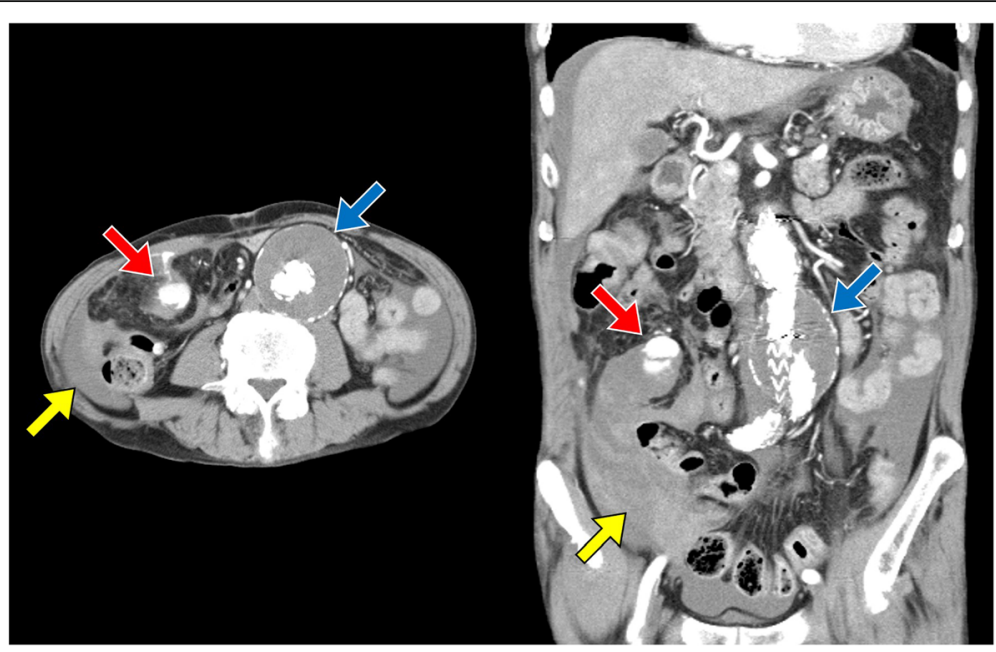

Fig. 3 Contrast-enhanced computed tomography obtained at the time of his abdominal pain (horizontal view [left] and coronal view [right]). The blue arrow indicates abdominal aortic aneurysm treated with stent grafting. The red arrow indicates the leakage of contrast medium from a branch of the right gastroepiploic artery. The yellow arrow indicates intra-abdominal bleeding

therapy to maintain extracorporeal circulation, as we did in this case at first. Low-molecular weight heparin has no definite evidence in patients with CES. We did not prefer low-molecular weight heparin given its relatively longer half-life in blood. Instead, we used nafamostat mesylate, which in turn has a disadvantage in its high cost.

For the patients with CES, some clinicians recommend peritoneal dialysis, which does not require any anticoagulation [15]. However, it is often not applicable given the frequent abdominal comorbidities including intestinal ischemia [16].

\section{CES and bleeding}

In patients with CES, cholesterol crystal emboli cause systemic end-organ dysfunction not only via microvascular obstruction but also via micro-vasculopathy. Consistently, the histopathological assessment showed cholesterol crystal embolization as well as infiltration of inflammatory cells and rupture of an omental artery. Cholesterol emboli would have caused vessel obstruction and inflammation, which resulted in the intra-abdominal bleeding.

There are few reports of bleeding events in patients with CES, except for a case of pulmonary bleeding [17] and another of intestinal bleeding accompanied by intestinal perforation [18]. We summarize the cases of CES that accompanied bleeding in Table 3. As shown, this is the first case of CES that accompanied intraperitoneal bleeding. In our case, heparin used during the hemodialysis might have worsened the severity of CES and caused intraperitoneal bleeding. We did not experience further bleeding events when nafamostat mesylate was used instead during the hemodialysis. Although there is no consensus thus far, we should be careful to select anticoagulants when patients with CES initiate

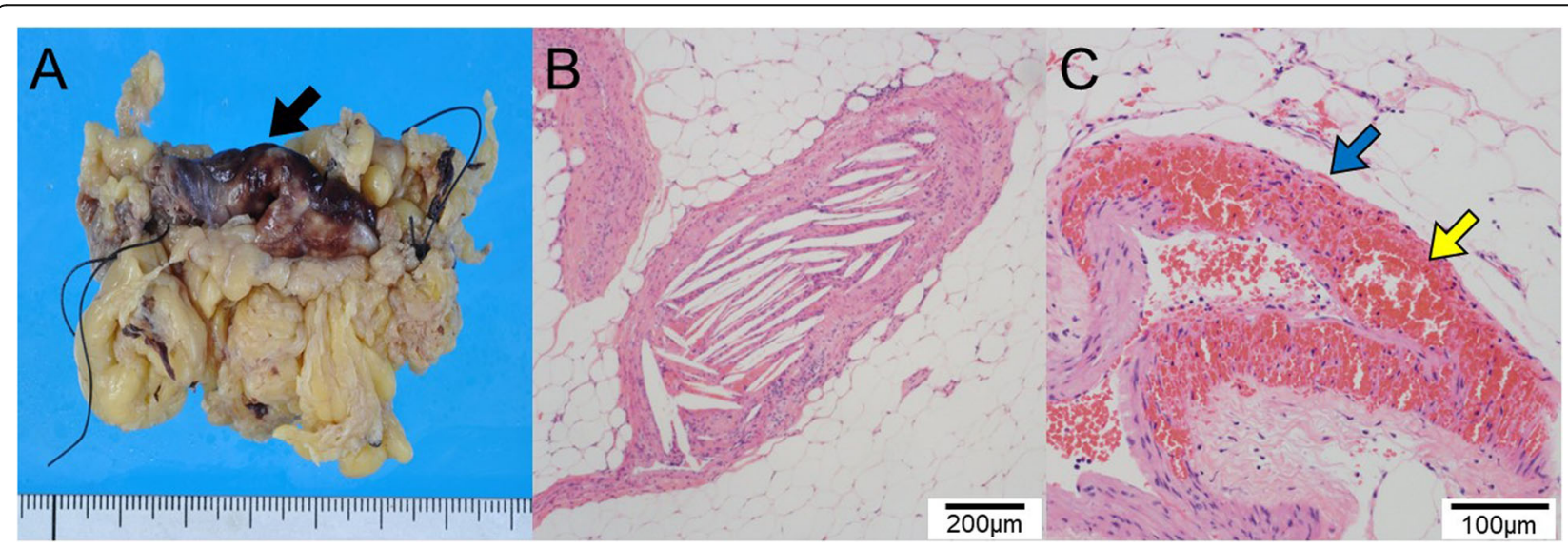

Fig. 4 Pathological findings of the resected omentum. a The resected omentum with hemorrhage (black arrow). b Massive cholesterol crystal clefts occluding arterioles of the omentum. $\mathbf{c}$ Inflammatory cell infiltration to arterial wall (blue arrow) and rupture of arterial wall and transmural bleeding (yellow arrow) 
Table 2 Overview of possible anticoagulants for hemodialysis in patients with CES

\begin{tabular}{|c|c|c|c|c|c|}
\hline Anticoagulant & $\begin{array}{l}\text { Heparin } \\
\text { (unfractionated) }\end{array}$ & $\begin{array}{l}\text { Low-molecular weight } \\
\text { heparin }\end{array}$ & Nafamostat mesylate & Argatroban & Citrate \\
\hline $\begin{array}{l}\text { Molecular } \\
\text { weight }\end{array}$ & $\begin{array}{l}5000-30,000 \\
\text { (average } 15,000 \text { ) }\end{array}$ & 2000-8000 (average 5000) & 540 & 527 & 192 \\
\hline Blood half-life & $60-90 \mathrm{~min}$ & $120-180 \mathrm{~min}$ & $5-8 \min$ & $15-30 \mathrm{~min}$ & $5 \mathrm{~min}$ \\
\hline $\begin{array}{l}\text { Mechanism of } \\
\text { anticoagulation }\end{array}$ & $\begin{array}{l}\text { Anti-factor Xa } \\
\text { Anti-thrombin }\end{array}$ & Anti-factor Xa & Inhibit serine protease & Anti-thrombin & Chelating $\mathrm{Ca}^{2+}$ \\
\hline Advantage & $\begin{array}{l}\text { Wide availability } \\
\text { Large experience } \\
\text { Low costs } \\
\text { Antagonist } \\
\text { available }\end{array}$ & $\begin{array}{l}\text { Lower bleeding risk than } \\
\text { unfractionated heparin }\end{array}$ & $\begin{array}{l}\text { Reduced bleeding risk } \\
\text { High costs }\end{array}$ & Adapted to HIT & $\begin{array}{l}\text { Strict regional } \\
\text { anticoagulation-reduced } \\
\text { bleeding risk }\end{array}$ \\
\hline Disadvantage & $\begin{array}{l}\text { Risk of bleeding } \\
\text { HIT }\end{array}$ & $\begin{array}{l}\text { No adequate reports of its } \\
\text { use in CES patients } \\
\text { HIT }\end{array}$ & $\begin{array}{l}\text { Rarely used outside of } \\
\text { Japan } \\
\text { No adequate reports of } \\
\text { its use in CES patients }\end{array}$ & $\begin{array}{l}\text { Risk of bleeding } \\
\text { No adequate reports of } \\
\text { its use in CES patients }\end{array}$ & $\begin{array}{l}\text { Rarely used in Japan } \\
\text { Metabolic complication } \\
\text { (alkalosis, hypocalcemia) } \\
\text { No adequate reports of its } \\
\text { use in CES patients }\end{array}$ \\
\hline
\end{tabular}

HIT heparin-induced thrombocytopenia

Table 3 Literature review of CES patients with bleeding events

\begin{tabular}{|c|c|c|c|c|c|c|c|c|}
\hline Reference & Age & Sex & $\begin{array}{l}\text { Invasive vascular } \\
\text { intervention }\end{array}$ & Anticoagulant & $\begin{array}{l}\text { Type of } \\
\text { bleeding }\end{array}$ & Pathology & Therapy & Outcome \\
\hline $\begin{array}{l}\text { Sabatine et al. } \\
\text { [17] }\end{array}$ & 69 & Male & None & Warfarin & $\begin{array}{l}\text { Pulmonary } \\
\text { hemorrhage }\end{array}$ & $\begin{array}{l}\text { Open-lung } \\
\text { biopsy }\end{array}$ & Supportive & Died \\
\hline $\begin{array}{l}\text { Moolenaar and } \\
\text { Lamers [18] }\end{array}$ & 69 & Male & None & None & $\begin{array}{l}\text { Bleeding } \\
\text { colonic ulcers }\end{array}$ & $\begin{array}{l}\text { Colon } \\
\text { biopsy }\end{array}$ & Resection & Survived \\
\hline $\begin{array}{l}\text { Moolenaar and } \\
\text { Lamers [18] }\end{array}$ & 68 & Female & None & $\begin{array}{l}\text { Oral } \\
\text { anticoagulant }\end{array}$ & $\begin{array}{l}\text { Melena } \\
\text { Duodenal } \\
\text { erosions }\end{array}$ & $\begin{array}{l}\text { Duodenum } \\
\text { biopsy }\end{array}$ & Supportive & Died \\
\hline $\begin{array}{l}\text { Moolenaar and } \\
\text { Lamers [18] }\end{array}$ & 71 & Male & Aortography & $\begin{array}{l}\text { Oral } \\
\text { anticoagulant }\end{array}$ & $\begin{array}{l}\text { Occult blood } \\
\text { loss } \\
\text { Duodenitis }\end{array}$ & $\begin{array}{l}\text { Duodenum } \\
\text { biopsy }\end{array}$ & Supportive & Died \\
\hline $\begin{array}{l}\text { Moolenaar and } \\
\text { Lamers [18] }\end{array}$ & 72 & Male & $\begin{array}{l}\text { Aortography } \\
\text { Aorta bifurcation } \\
\text { prosthesis }\end{array}$ & None & $\begin{array}{l}\text { Rectal } \\
\text { bleeding } \\
\text { Sigmoid } \\
\text { necrosis }\end{array}$ & $\begin{array}{l}\text { Sigmoid } \\
\text { resection }\end{array}$ & Resection & Died \\
\hline Our case & 68 & Male & $\begin{array}{l}\text { Coronary } \\
\text { angiography } \\
\text { Coronary artery } \\
\text { bypass grafting } \\
\text { Endovascular } \\
\text { aneurysm repair }\end{array}$ & $\begin{array}{l}\text { Heparin for } \\
\text { hemodialysis }\end{array}$ & $\begin{array}{l}\text { Intra- } \\
\text { abdominal } \\
\text { bleeding } \\
\text { Omental } \\
\text { bleeding }\end{array}$ & $\begin{array}{l}\text { Omentum } \\
\text { resection }\end{array}$ & Resection & Died from sepsis unrelated to CES \\
\hline
\end{tabular}


hemodialysis. In conclusion, not only the embolic events, but also the bleeding events can develop in patients with CES, particularly following the initiation of hemodialysis with anticoagulation therapy.

\section{Abbreviations}

CES: Cholesterol embolization syndrome

\section{Acknowledgements}

Not applicable.

\section{Authors' contributions}

KK, TK, YA, SM, AS, TK, and HY provided clinical discussion and treatment of the patient. KK, TK, and TI drafted the manuscript. KK reviewed and revised the manuscript. All authors read and approved the final manuscript.

\section{Funding}

The authors confirm that they received no funding for this report.

\section{Availability of data and materials}

All data and materials were included in the manuscript.

\section{Ethics approval and consent to participate}

All procedures performed in this case were in accordance with the ethical standards of the 1964 Helsinki Declaration.

\section{Consent for publication}

Informed consent was obtained from the patient for the publication of this case report.

\section{Competing interests}

The authors declare that they have no competing interests.

Received: 19 August 2020 Accepted: 13 November 2020

Published online: 23 November 2020

\section{References}

1. Fine MJ, Kapoor W, Falanga V. Cholesterol crystal embolization: a review of 221 cases in the English literature. Angiology. 1987;38:769-84.

2. Kronzon I, Saric M. Cholesterol embolization syndrome. Circulation. 2010; 122:631-41.

3. Kasinath BS, Corwin HL, Bidani AK, Korbet SM, Schwartz MM, Lewis EJ. Eosinophilia in the diagnosis of atheroembolic renal disease. Am J Nephrol. 1987;7:173-7.

4. Ozkok A. Cholesterol-embolization syndrome: current perspectives. Vasc Health Risk Manag. 2019;15:209-20.

5. Carroccio A, Olin JW, Ellozy SH, Lookstein RA, Valenzuela R, Minor ME, et al The role of aortic stent grafting in the treatment of atheromatous embolization syndrome: results after a mean of 15 months follow-up. J Vasc Surg. 2004;40:424-9.

6. Fukumoto Y, Tsutsui H, Tsuchihashi M, Masumoto A, Takeshita A. The incidence and risk factors of cholesterol embolization syndrome, a complication of cardiac catheterization: a prospective study. J Am Coll Cardiol. 2003:42:211-6.

7. Modi KS, Rao VK. Atheroembolic renal disease. J Am Soc Nephrol. 2001;12: 1781-7.

8. Scolari F, Ravani P. Atheroembolic renal disease. Lancet (London, England) 2010;375:1650-60

9. Lye WC, Cheah JS, Sinniah R. Renal cholesterol embolic disease. Case report and review of the literature. Am J Nephrol. 1993;13:489-93.

10. Thadhani Rl, Camargo CA Jr, Xavier RJ, Fang LS, Bazari H. Atheroembolic renal failure after invasive procedures. Natural history based on 52 histologically proven cases. Medicine. 1995;74:350-8.

11. Belenfant $X$, Meyrier A, Jacquot C. Supportive treatment improves survival in multivisceral cholesterol crystal embolism. Am J Kidney Dis. 1999;33:840-50.

12. Scolari F, Ravani P, Gaggi R, Santostefano M, Rollino C, Stabellini N, et al. The challenge of diagnosing atheroembolic renal disease: clinical features and prognostic factors. Circulation. 2007;116:298-304.
13. Hitti WA, Wali RK, Weinman EJ, Drachenberg C, Briglia A. Cholesterol embolization syndrome induced by thrombolytic therapy. Am J Cardiovasc Drugs. 2008;8:27-34

14. Blankenship JC, Butler M, Garbes A. Prospective assessment of cholesterol embolization in patients with acute myocardial infarction treated with thrombolytic vs conservative therapy. Chest. 1995;107:662-8.

15. Mizuno M, Ito $Y$, Hayasaki T, Suzuki $Y$, Hiramatsu H, Toda S, et al. A case of acute renal failure caused by cholesterol embolization after carotid artery stenting that was improved by peritoneal dialysis. Intern Med. 2011;50: 1719-23.

16. Gillerot $G$, Sempoux C, Pirson Y, Devuyst O. Which type of dialysis in patients with cholesterol crystal embolism? Nephrol Dial Transplant. 2002; 17:156-8.

17. Sabatine MS, Oelberg DA, Mark EJ, Kanarek D. Pulmonary cholesterol crystal embolization. Chest. 1997:112:1687-92.

18. Moolenaar W, Lamers CB. Gastrointestinal blood loss due to cholesterol crystal embolization. J Clin Gastroenterol. 1995;21:220-3.

\section{Publisher's Note}

Springer Nature remains neutral with regard to jurisdictional claims in published maps and institutional affiliations.
Ready to submit your research? Choose BMC and benefit from:

- fast, convenient online submission

- thorough peer review by experienced researchers in your field

- rapid publication on acceptance

- support for research data, including large and complex data types

- gold Open Access which fosters wider collaboration and increased citations

- maximum visibility for your research: over $100 \mathrm{M}$ website views per year

At BMC, research is always in progress.

Learn more biomedcentral.com/submission 